INEL-94/0009

\title{
Health and Safety Plan for Characterization Sampling of ETR and MTR Facilities
}

\author{
D. E. Baxter
}

Published September 1994

\begin{abstract}
Idaho National Engineering Laboratory Lockheed Idaho Technologies Company Idaho Falls, Idaho $\mathbf{8 3 4 1 5}$
\end{abstract}

\section{Prepared for the} U.S. Department of Energy

Assistant Secretary for Environmental Management Under DOE Idaho Operations Office

Contract DE-AC07-94ID13223

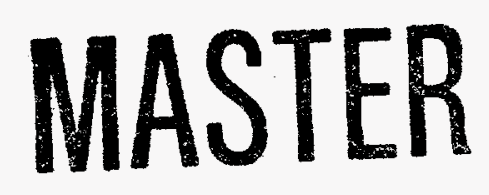




\section{DISCLAIMER}

This report was prepared as an account of work sponsored by an agency of the United States Government. Neither the United States Government nor any agency thereof, nor any of their employees, makes any warranty, express or implied, or assumes any legal liability or responsibility for the accuracy, completeness, or usefulness of any information, apparatus, product, or process disclosed, or represents that its use would not infringe privately owned rights. Reference herein to any specific commercial product, process, or service by trade name, trademark, manufacturer, or otherwise does not necessarily constitute or imply its endorsement, recommendation, or favoring by the United States Government or any agency thereof. The views and opinions of authors expressed herein do not necessarily state or reflect those of the United States Government or any agency thereof. 


\section{DISCLAIMER}

Portions of this document may be illegible in electronic image products. Images are produced from the best available original document. 


\section{Health and Safety Plan for Characterization Sampling of ETR and MTR Facilities}

INEL-94/0009

Approved by:

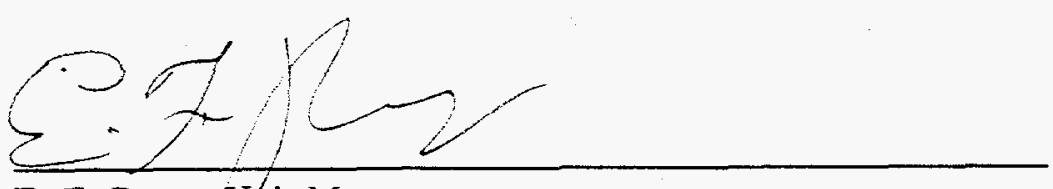

E. F. Perry, Uhit Manager

Decontamination and Decommissioning Unit

Reviewed by:

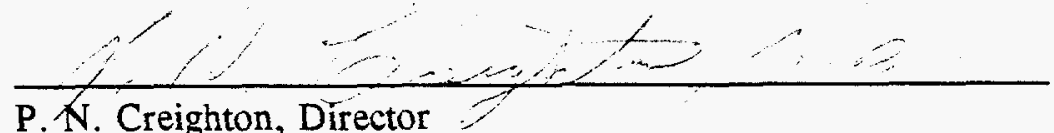
Occupational Medical Program

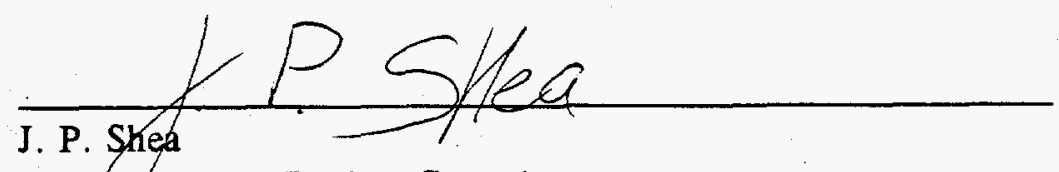

ER Independent Review Committee

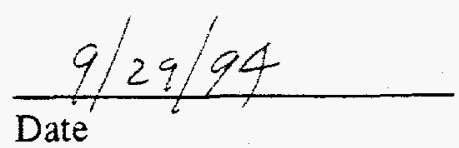

Date

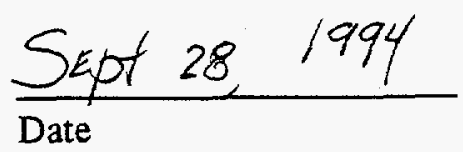




\begin{abstract}
This health and safety plan establishes the procedures and requirements that will be used to minimize health and safety risks to persons performing Engineering Test Reactor and Materials Test Reactor characterization sampling activities, as required by the Occupational Safety and Health Administration standard, 29 CFR 1910.120. It contains information about the hazards involved in performing the tasks, and the specific actions and equipment that will be used to protect persons working at the site.
\end{abstract}




\section{CONTENTS}

ABSTRACT $\ldots \ldots \ldots \ldots \ldots \ldots \ldots \ldots \ldots \ldots \ldots \ldots \ldots \ldots \ldots \ldots \ldots \ldots$

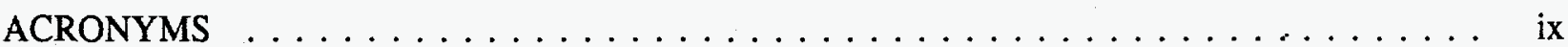

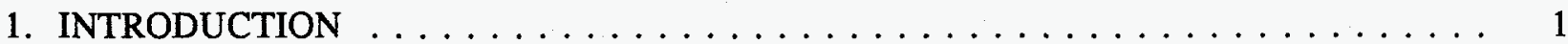

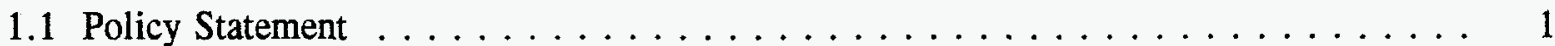

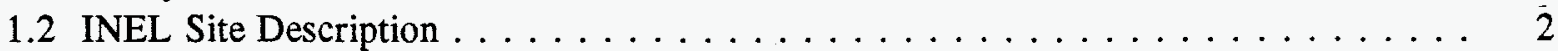

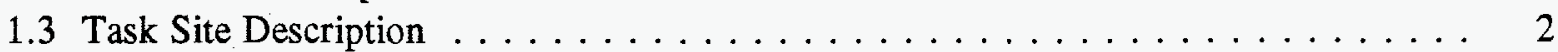

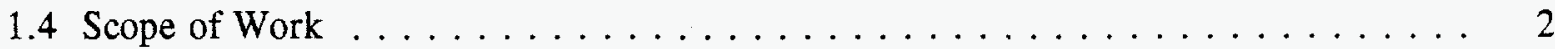

2. TASK SITE RESPONSIBILITIES $\ldots \ldots \ldots \ldots \ldots \ldots \ldots \ldots \ldots \ldots$

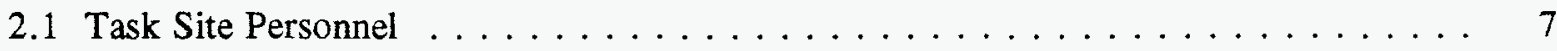

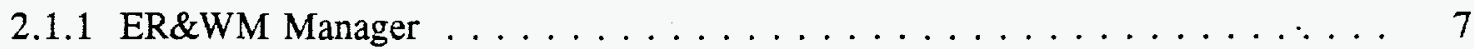

2.1 .2 Project Manager . . . . . . . . . . . . . . . . . . . 7

2.1 .3 Field Team Leader $\ldots \ldots \ldots \ldots \ldots \ldots \ldots \ldots$

2.1 .4 Job Site Supervisor $\ldots \ldots \ldots \ldots \ldots \ldots \ldots$

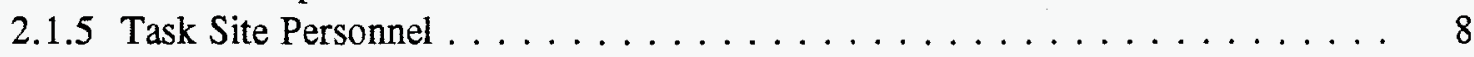

2.1 .6 Nonworkers . . . . . . . . . . . . . . . . . . . . . 8

2.1 .7 Other Site Visitors $\ldots \ldots \ldots \ldots \ldots \ldots \ldots \ldots$

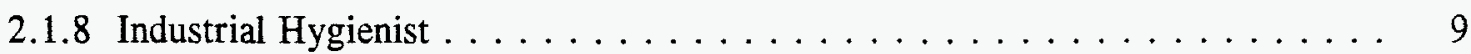

2.1 .9 Safety Engineer . . . . . . . . . . . . . . . . . . . . . . . . . . . . . . . .

2.1.10 Radiological Control Technician ................... . 9

2.1.11 Radiological Engineer . . . . . . . . . . . . . . . . . . 9

2.1 .12 Occupational Medical Program . . . . . . . . . . . . . . . 10

2.1 .13 Quality Engineer . . . . . . . . . . . . . . . . . . . . 10

2.1 .14 TRA Landlord . . . . . . . . . . . . . . . . . . . . . 10

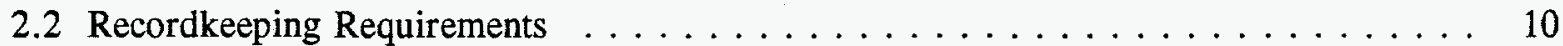

2.2.1 Industrial Hygiene and Radiological Monitoring Records . . . . . . . . . . 10

2.2.2 FTL Logbook and Site Attendance Logbook . . . . . . . . . . . . . . . . . . . . . . . . . . . . . . . .

2.2.3 Document Control Office ..................... 11

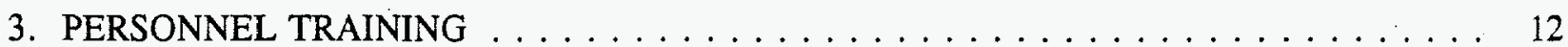

4. OCCUPATIONAL MEDICINE PROGRAM AND MEDICAL SURVEILLANCE $\ldots \ldots \ldots$

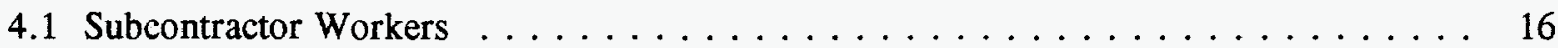

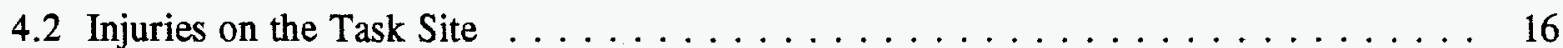

4.3 Substance-Specific Medical Surveillance $\ldots \ldots \ldots \ldots \ldots \ldots$

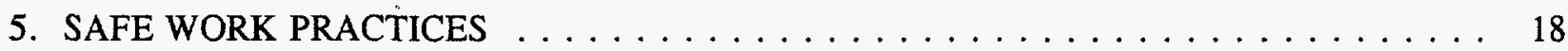

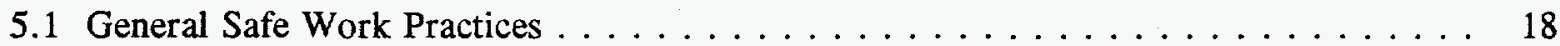

5.2 ALARA Principles . . . . . . . . . . . . . . . . . . . . . 19

5.3 The Buddy System . . . . . . . . . . . . . . . . . . 20

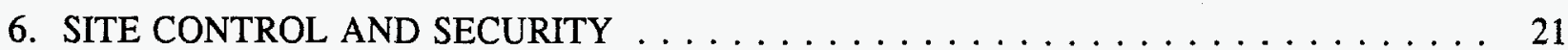

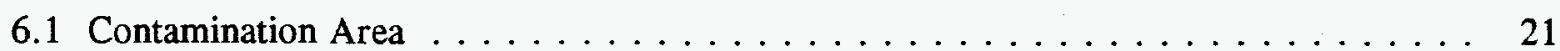




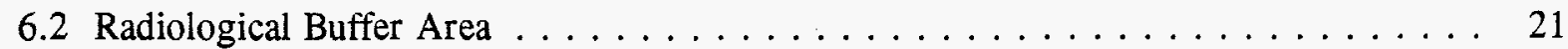

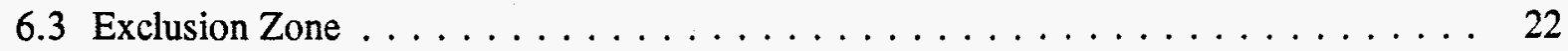

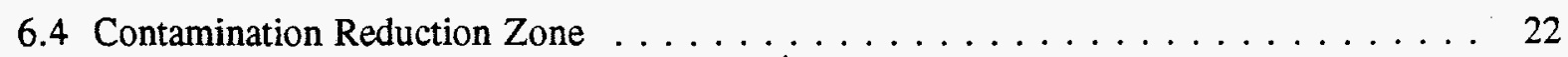

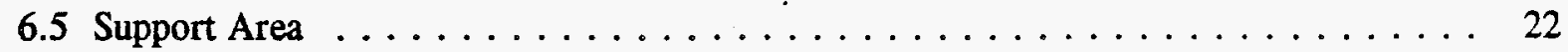

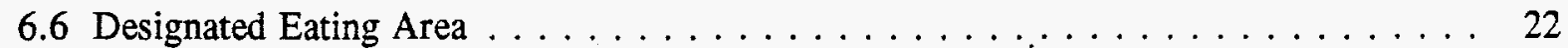

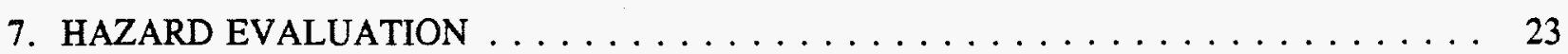

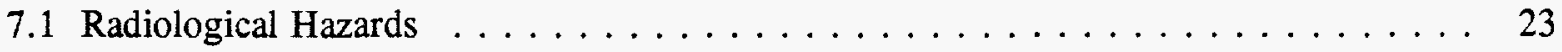

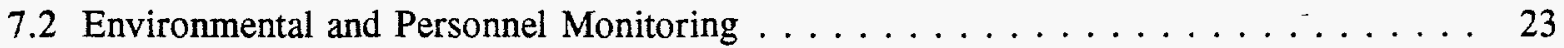

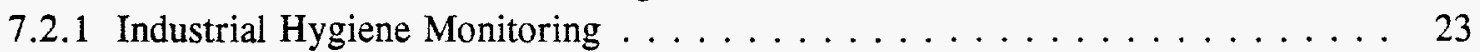

7.2 .2 Radiological Monitoring . . . . . . . . . . . . . . . . . . . . . . . . . . . . . .

7.3 Physical Hazards Evaluation, Control, and Monitoring . . . . . . . . . . . . 29

7.3 .1 Temperature Extremes . . . . . . . . . . . . . . . . . . . . . . 29

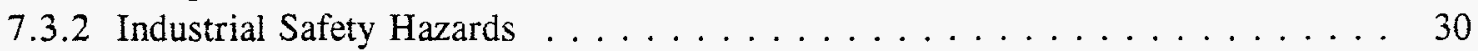

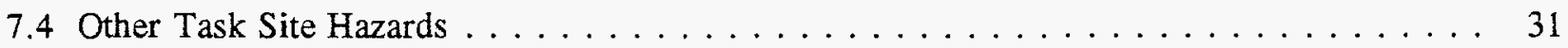

8. PERSONAL PROTECTIVE EQUIPMENT $\ldots \ldots \ldots \ldots \ldots \ldots \ldots \ldots \ldots \ldots \ldots$

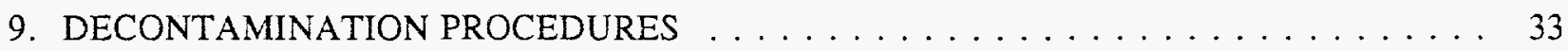

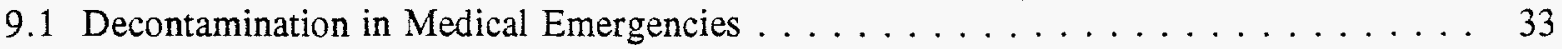

9.2 Equipment Decontamination and Disposal $\ldots \ldots \ldots \ldots \ldots \ldots \ldots \ldots$

9.3 Site Sanitation and Waste Minimization . . . . . . . . . . . . . . 33

10. EMERGENCY RESPONSE PLAN FOR TASK SITE $\ldots \ldots \ldots \ldots \ldots \ldots \ldots$

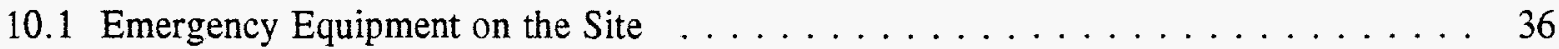

10.2 Telephone/Radio Contact Reference List for TRA (ETR/MTR) Sampling . . . . . . . 36

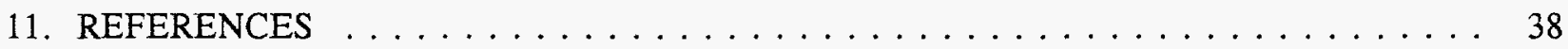

12. HEALTH AND SAFETY PLAN TRAINING ACKNOWLEDGEMENT $\ldots \ldots \ldots$

FIGURES

1. Idaho National Engineering Laboratory site plan . . . . . . . . . . . . . 3

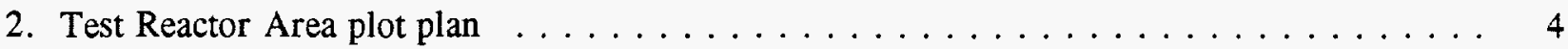

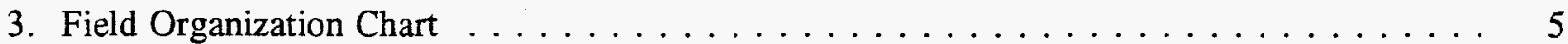

\section{TABLES}

1. Required training for task site personnel . . . . . . . . . . . . . . . . 13

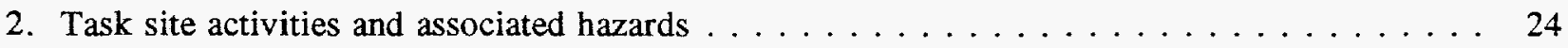

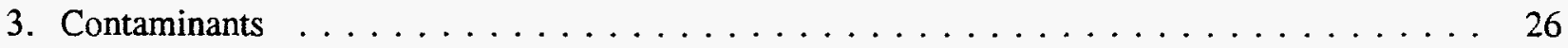

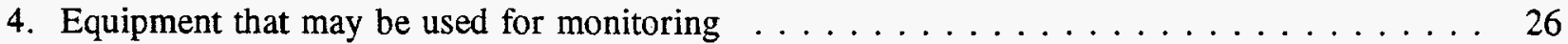

Radiological monitoring equipment . . . . . . . . . . . . . . . . . . 29

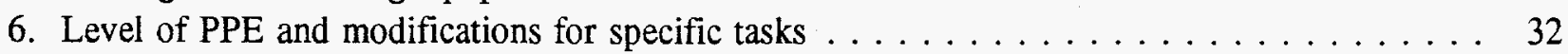




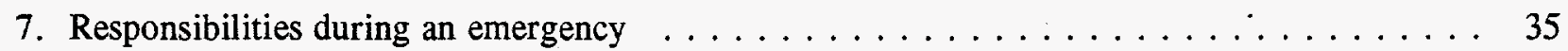




\section{ACRONYMS}

\begin{tabular}{|c|c|}
\hline ALARA. & as low as reasonably achievable \\
\hline ATR & Auxiliary Test Reactor \\
\hline CAM & constant air monitor \\
\hline CFA & Central Facilities Area \\
\hline CFR & Code of Federal Regulations \\
\hline $\mathrm{D} \& \mathrm{D}$ & decontamination and decommissioning \\
\hline DOE & U.S. Department of Energy \\
\hline DOE-ID & DOE Idaho Operations Office \\
\hline EPA & U.S. Environmental Protection Agency \\
\hline ER\&WM & Environmental Restoration and Waste Management Department \\
\hline ERP & Environmental Restoration Program \\
\hline ETR & Engineering Test Reactor \\
\hline$F \& M$ & Facilities and Maintenance Department \\
\hline FTL & field team leader \\
\hline HSP & health and safety plan \\
\hline IH & industrial hygienist \\
\hline INEL & Idaho National Engineering Laboratory \\
\hline JSS & job site supervisor \\
\hline MTR & Materials Test Reactor \\
\hline NRTS & National Reactor Testing Station \\
\hline OMP & Occupational Medical Program \\
\hline OSHA & Occupational Safety and Health Administration \\
\hline PM & project manager \\
\hline
\end{tabular}


personal protective equipment

PSG

Program Support Group

RAM

radiation area monitor

RBA

radiological buffer area

RCT

radiológical control technician

TRA

Test Reactor Area

USCG

U.S. Coast Guard

WCC

Warning Communications Center 


\section{Health and Safety Plan for Characterization Sampling of ETR and MTR Facilities}

\section{INTRODUCTION}

This health and safety plan (HSP) establishes the procedures and requirements that will be used to minimize health and safety risks to persons working at the task site. This HSP has been prepared to meet the requirements of the Occupational Safety and Health Administration (OSHA) standard 29 CFR 1910.120, "Hazardous Waste Operations and Emergency Response." It has been prepared in recognition of and is consistent with NIOSH/OSHA/USCG/EPA Occupational Safety and Health Guidance Manual for Hazardous Waste Site Activities [National Institute of Occupational Safety and Health (NIOSH), 1985]; the EG\&G Idaho Safety Manual; the EG\&G Idaho Radiological Controls Manual; the EG\&G Idaho Industrial Hygiene Manual; the EG\&G Idaho Company Procedures Manual; and the U.S. Environmental Protection Agency (EPA) Standard Operating Safety Guides (EPA 1984). It is planned to evaluate the sampling tasks in accordance with EG\&G Idaho Company Procedures Manual, Section 7.3, Unreviewed Safety Questions (USQ) determinations in respect to the ETR Inactivation SAR, and the SAR for ER Characterization Sampling, EGG-ERD-10335, Rev 1.

This HSP shall govern all work at the task site that is performed by employees of EG\&G Idaho, subcontractors to EG\&G Idaho, and employees of other companies or U.S. Department of Energy (DOE) laboratories. Persons not normally assigned to work at the task site, such as representatives of DOE, the State of Idaho, OSHA, and the EPA, shall be considered nonworkers and fall under the definition of occasional site workers as stated in OSHA 29 CFR 1910.120. Modifications to the plan may be implemented by the field team leader (FTL) with concurrence from the safety engineer (SE), industrial hygienist $(\mathrm{IH})$, the cognizant radiological control technician (RCT), the project manager (PM), and the job site supervisor (JSS). Changes or additions to the plan, along with rationale for the change, will be recorded in the daily activity log and communicated to the team members by the FTL.

\subsection{Policy Statement}

It is the general policy of EG\&G Idaho that all operations will be carried out in compliance with all recognized national and regional regulations related to safety, health, and environmental protection.

Additionally, EG\&G Idaho is committed to conducting all operations safely and establishing procedures and practices to prevent the inadvertent or uncontrolled release of pollutants to the environment. In conducting these activities, first priority is given to worker safety, environmental health, and protection of the public. Safety will not be compromised or subordinated to cost or schedule pressures.

Considering the location and nature of the work, as low as reasonably achievable (ALARA) principles will be an important consideration. The ALARA principles will apply to all aspects of radiation and contamination control. Every reasonable precaution shall be taken to keep radiation dose ALARA. 
Activities conducted in accordance with this policy will be in compliance with OSHA and EPA regulations governing hazardous waste operations. All EG\&G Idaho employees who conduct, supervise, or manage hazardous waste operations are responsible for carrying out activities in compliance with the provisions of this policy.

\subsection{INEL Site Description}

The Idaho National Engineering Laboratory (INEL), formerly the National Reactor Testing Station (NRTS), encompasses 894 square miles and is located west of Idaho Falls, Idaho (Figure 1). The U.S. Atomic Energy Commission, now the U.S. Department of Energy (DOE), established the NRTS in 1949 as a site for building and testing a variety of nuclear facilities. The INEL has also been the storage facility for transuranic radionuclides and low-level radioactive waste since 1952 . At present, the INEL supports engineering and operations efforts of DOE and other Federal agencies in areas of nuclear safety research, reactor development, reactor operations and training, nuclear defense materials production, waste management technology development, and energy technology and conservation programs. The DOE Idaho Operations Office (DOE-ID) has responsibility for the INEL, and designates authority to operate the INEL to government contractors. The primary contractor for DOE-ID at the INEL is EG\&G Idaho, Inc., which provides managing and operating services to the majority of the INEL facilities.

\subsection{Task Site Description}

The oldest of the INEL test reactors, the Materials Test Reactor (MTR), was first operated in 1952 and was the second reactor to be operated at the INEL. Successful operation resulted in the development of several plate-type reactors. The Engineering Test Reactor (ETR) was first operated in 1957. The ETR evolved from the demand for high flux testing space, more stable flux, a greater variety of flux levels than the MTR could provide, and the need for through-the-core facilities. In 1970, the MTR was deactivated; the ETR was deactivated in 1981.

The ETR/MTR complex consists of 37 facilities within the Test Reactor Area (TRA). The TRA site plot plan is shown in Figure 2. This HSP addresses sampling activities within specific buildings and areas. The following buildings or areas will be covered by this HSP: TRA-611, MTR plug storage; TRA-612, MTR retention basin sump pump house; TRA-642, ETR reactor building; TRA643, ETR compressor building; TRA-644, ETR heat exchanger building; TRA-645, ETR secondary coolant pump house; TRA-647, ETR office building; TRA-648, ETR electrical building; TRA-655, ETR experiment air in-take building; TRA-663, ETR superior diesel building; TRA-704, ETR primary filter pit; TRA-705, ETR secondary filter pit; TRA-706, ETR exhaust delay tanks; and TRA755, ETR filter pit building.

\subsection{Scope of Work}

The preliminary assessment work to be performed will assist EG\&G Idaho in determining if environmental contamination (chemical and radiological) is still present from past activities at the ETR and MTR facilities and, if contamination is found, the samples will be used to help 


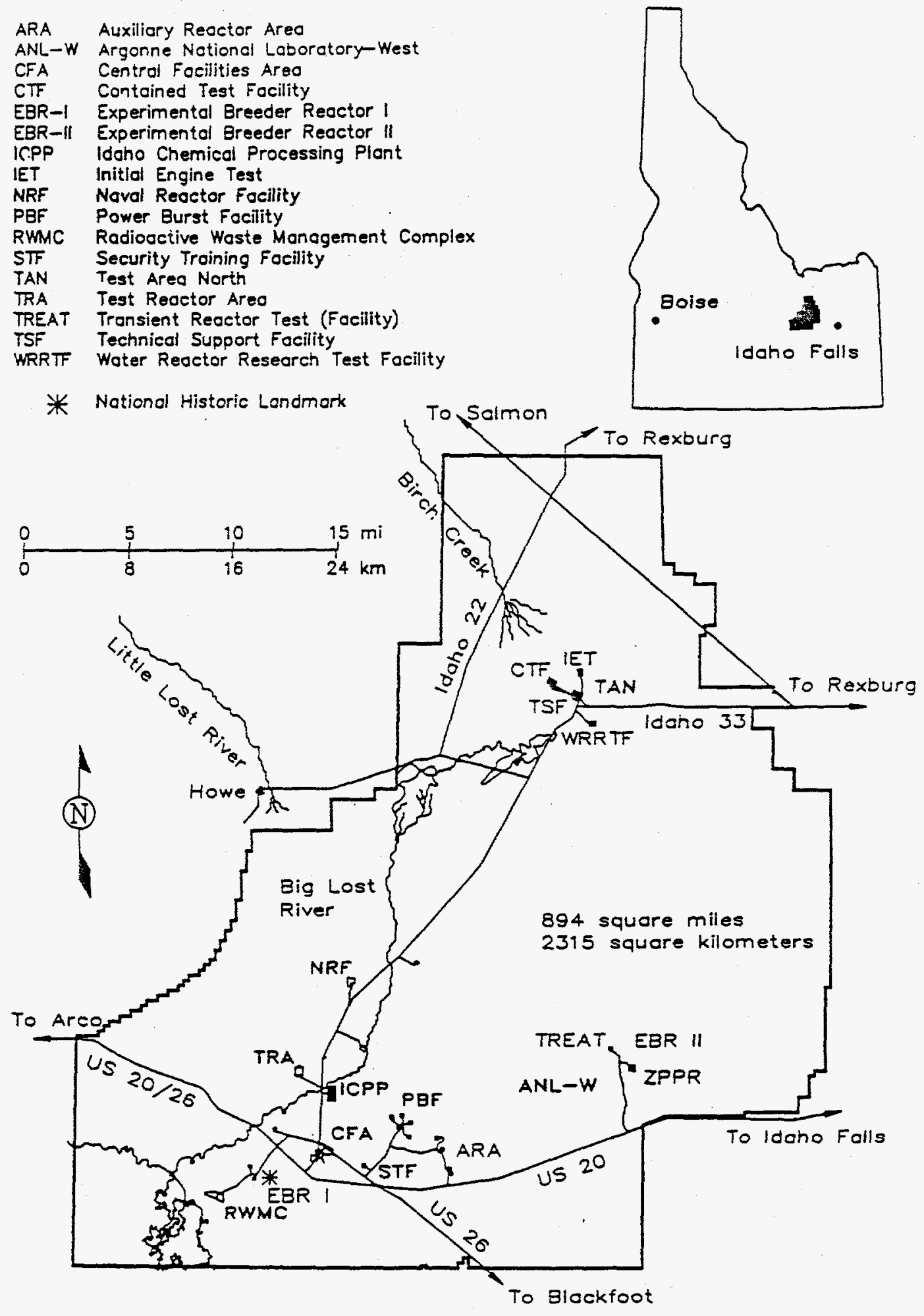

Figure 1. Idaho National Engineering Laboratory site plan. 


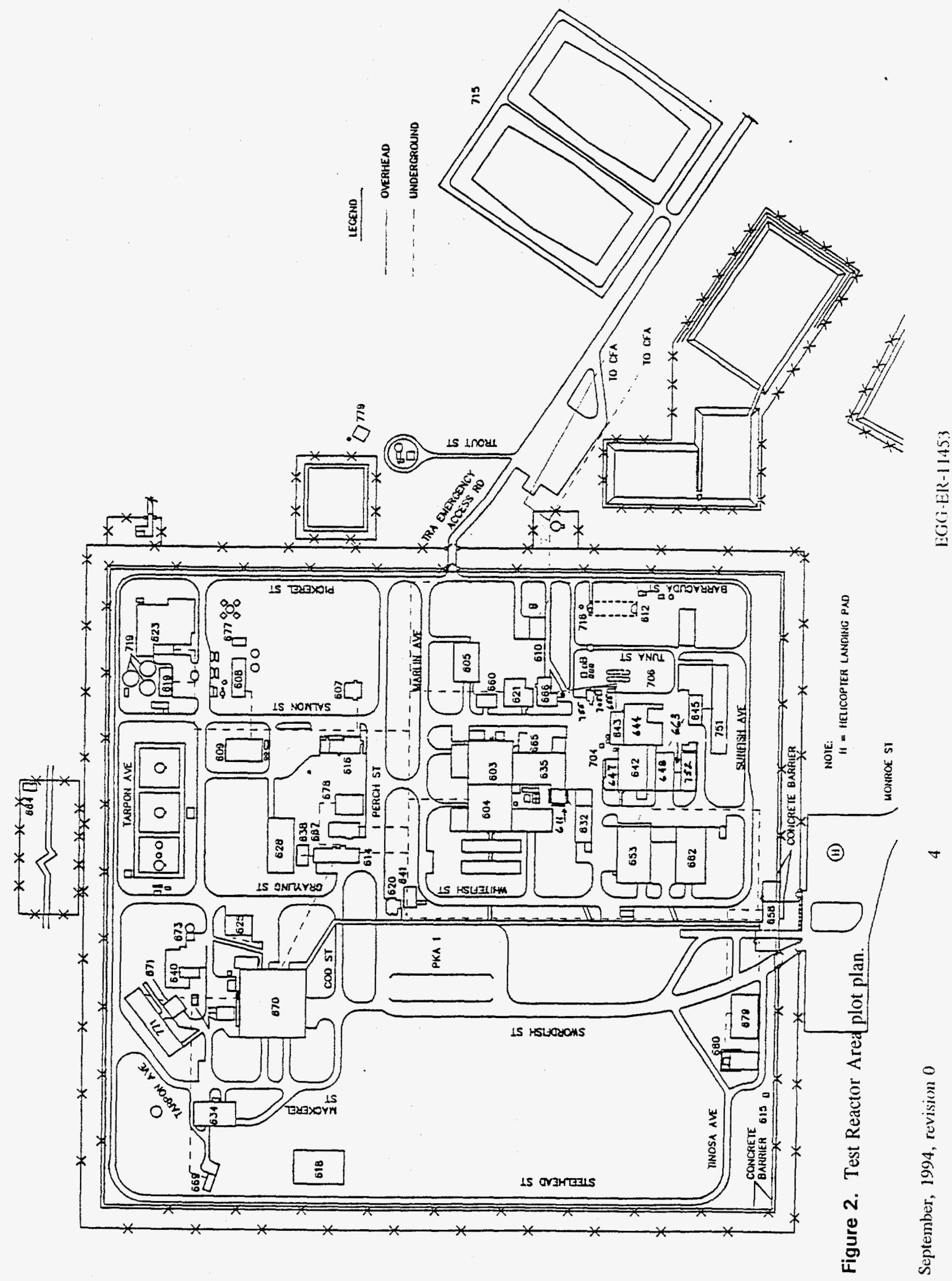




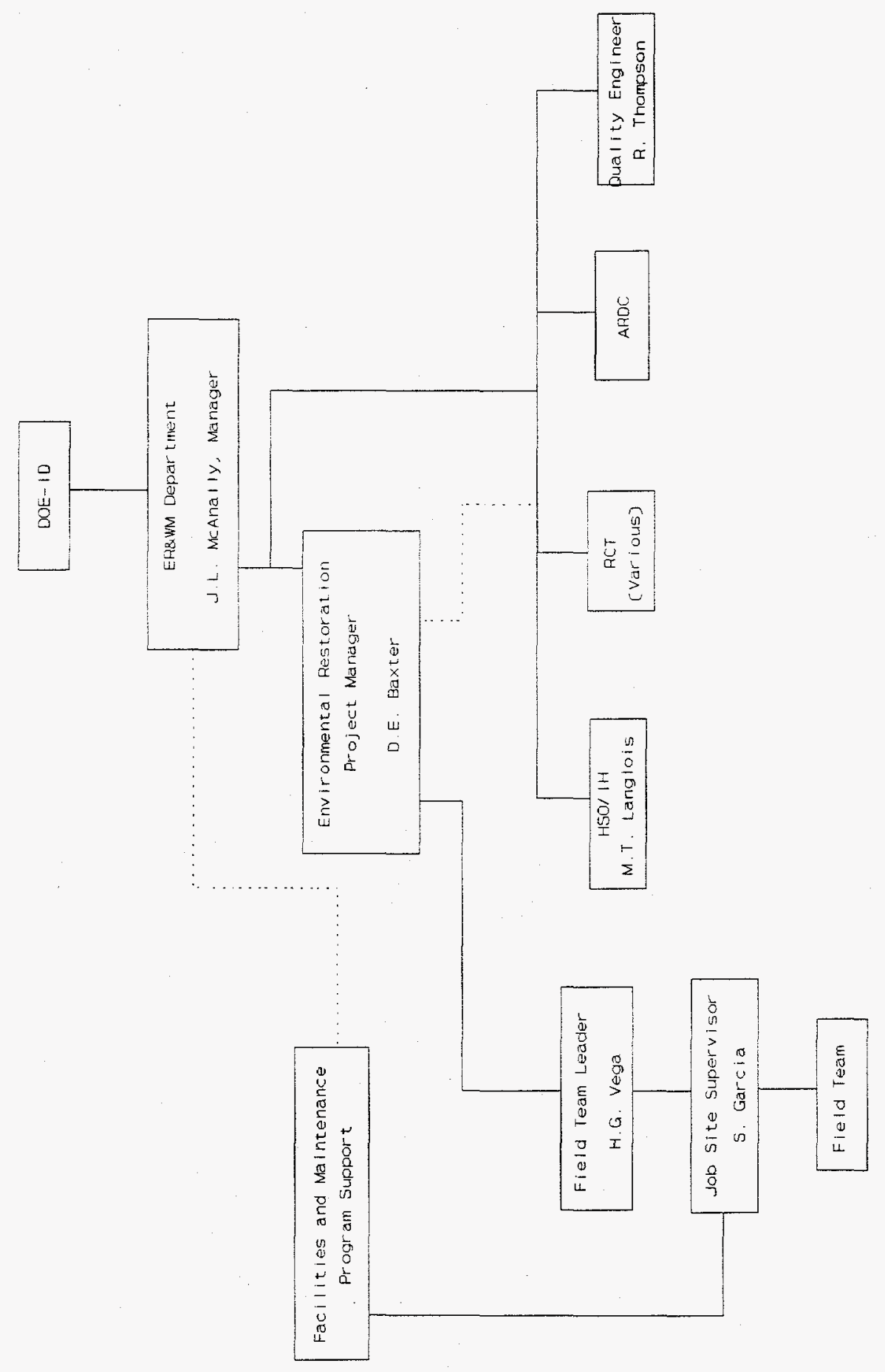


determine the magnitude and extent of the contamination. The decontamination and decommissioning (D\&D) activities of these facilities and areas are not addressed or covered in this HSP.

Field activities in support of the EG\&G Idaho investigation consist of:

- Collecting composite surface soil samples

- Collecting grab samples at depth using hand augers

- Collecting smear samples and radiation readings within the facilities

- $\quad$ Collecting samples from pits, drains, and sumps, if possible.

The specific sampling approach is delineated in the Abbreviated Sampling and Analysis Plan for Planning Decontamination and Decommissioning at Test Reactor Area (TRA) Facilities (EGG-ER11504). The field activities that will be conducted may involve exposure to hazardous materials or waste resulting from direct contact with contaminated soil, rock, and groundwater during sampling operations. The maintenance of good health and provision for the safety of onsite personnel will be of major concern during field activities at the investigation site. 


\section{TASK SITE RESPONSIBILITIES}

\subsection{Task Site Personnel}

The organizational structure for this task reflects the resources and expertise required to perform the task, while minimizing risks to worker health and safety. The following subsections outline responsibilities of key site personnel.

\subsubsection{ER\&WM Manager}

The Environmental Restoration and Waste Management Department (ER\&WM) manager has ultimate responsibility for the technical quality of all projects and safety of personnel during field activities performed by or for the Environmental Restoration Program (ERP). The ER\&WM manager provides technical coordination and interfaces with the DOE-ID Environmental Support Office. The ER\&WM manager:

- Ensures that all activities are conducted in accordance with DOE, EPA, and State of İaho requirements and agreements

- Ensures the availability of necessary personnel, equipment, subcontractors, and services

- Provides direction for the development of tasks, evaluation of findings, development of conclusions and recommendations, and production of reports.

\subsubsection{Project Manager}

The PM has responsibility for ensuring that all activities conducted during the project are in compliance with the Management Plans for the EG\&G Idaho Environmental Restoration Program and all applicable OSHA, EPA, DOE, U.S. Department of Transportation, and State of Idaho requirements. The PM is responsible for ensuring that tasks comply with the Quality Program Plan for the Environmental Restoration Program (QPP-149), this HSP, and project directives. The PM coordinates all field activities and will ensure that all activities are performed in accordance with Company procedures.

\subsubsection{Field Team Leader}

The FTL is the individual representing ERP at the task site, with responsibility for the safe and successful completion of the project. The FTL works with the JSS to manage field operations and execute the work plan. The FTL and JSS conduct daily safety briefings to the crew at the start of the shift. All health and safety issues at the task site must be brought to the attention of the FTL.

If the FTL leaves the task site, an alternate individual will be appointed to act as the FTL.

Persons acting as FTL on the task site must meet all training requirements for the FTL, as outlined in Section 3. The identity of the acting FTL shall be conveyed to task site personnel and recorded in the FTL logbook. 


\subsubsection{Job Site Supervisor}

The JSS serves as the representative for the Facilities and Maintenance Department (F\&M) Program Support Group (PSG) at the task site. The JSS is the supervisor of crafts and other F\&M PSG personnel who are assigned to work at the site. The JSS is the interface between F\&M PSG and ERP, and works closely with ERP personnel at the site (FTL and PM) to ensure that the objectives of the project are accomplished in a safe and efficient manner. The JSS and FTL work as a team to accomplish day-to-day operations at the task site, identify and obtain additional resources needed at the site, and interact with the IH, safety engineer, radiological engineer, and RCT on matters regarding health and safety. The JSS, like the FTL, must be informed of any health and safety issues that arise at the task site and may stop work at the site if an unsafe condition exists. The JSS also shares the FTL's responsibility for daily pre-work briefings.

\subsubsection{Task Site Personnel}

All task personnel, including EG\&G Idaho and subcontractor personnel, are responsible for understanding and complying with the requirements of this HSP. Task site personnel will be briefed by the FTL or JSS at the start of each shift. Task site personnel should report potentially unsafe situations or conditions to the FTL or JSS for corrective action. If unsafe conditions develop, task site personnel are authorized to stop work and notify the FTL or JSS of the unsafe condition. Task site personnel will primarily be supplied from the F\&M PSG.

\subsubsection{Nonworkers}

All persons who may be on the task site that are not a part of the field team at the project site are considered nonworkers for the purposes of this project. A person shall be considered to be "on site" when they are present in or beyond the designated support zone. Nonworkers will be deemed occasional site workers per 29 CFR 1910.120, and must meet minimum training requirements for such workers as described in the OSHA standard, and any additional task-specific training that is specified in Section 3 of this HSP.

All nonworkers, including EG\&G Idaho employees from other departments and representatives of DOE, or State or Federal regulatory agencies, may not proceed beyond the support zone without receiving a safety briefing, wearing the appropriate protective equipment, and providing proof of meeting the training requirements specified in Section 3 of this HSP. Nonworkers will be escorted by a fully trained task site representative (such as the FTL, JSS, or a designated alternate) at all times while on site.

\subsubsection{Other Site Visitors}

A casual visitor to the site is a person who does not have a specific task to perform or other official business to conduct at the site. Casual visitors are not permitted in the task site work area. 


\subsubsection{Industrial Hygienist}

The IH is the primary source of information regarding non-radiological hazardous and toxic agents at the task site. The IH assesses the potential for worker exposures to hazardous agents in accordance with Company procedures and the EG\&G Idaho Industrial Hygiene Manual. The IH recommends appropriate hazard controls for protection of task site personnel, reviews the effectiveness of monitoring and personal protective equipment (PPE) required in this HSP, and recommends changes as appropriate. Following an evacuation, the $\mathrm{IH}$ will assist in determining whether conditions at the task site are safe for reentry. Employees showing health effects resulting from possible exposure to hazardous agents will be referred to the Occupational Medical Program (OMP) by the IH. The IH may also perform air sampling to evaluate the presence of combustible mixtures of gases, and toxic or low-oxygen atmospheres. The IH may have other duties at the task site as specified in other sections of this HSP, or in Company procedures and manuals.

\subsubsection{Safety Engineer}

The safety engineer reviews work packages, observes site activity, advises the FTL on required safety equipment, and recommends solutions to industrial safety issues that arise at the task site. The safety engineer may have other duties at the task site as specified in other sections of this HSP, or in Company procedures or manuals.

\subsubsection{Radiological Control Technician}

The RCT is a source of information and guidance on radiological hazards. The RCT will be available during any task operations when a radiological hazard to operations personnel may exist or is anticipated. Responsibilities of the RCT include radiological surveying of the task site, equipment, and samples; providing guidance for work activities; and accompanying the affected personnel to the nearest INEL medical facility for evaluation if significant radiological contamination occurs. The RCT and/or radiological engineer must notify the FTL of any radiological occurrence that must be reported as directed by the "EG\&G Conduct of Operations Manual", Section VII, Notifications. The RCT may have other duties at the task site as specified in other sections of this HSP, or in Company procedures and manuals.

\subsubsection{Radiological Engineer}

The radiological engineer is a source of information and guidance relative to the evaluation and control of radioactive hazards at the task site. The radiological engineer makes recommendations to minimize health and safety risks of task operations personnel if a radiological hazard exists or occurs at the task site. Responsibilities of the radiological engineer include technical work control document review/approval, perform ALARA evaluations, observe site work activities; identify the type(s) of radiological monitoring equipment necessary for the task; advise the FTL and RCT of changes in monitoring or PPE, and advising on task site evacuation and reentry. The radiological engineer may also have other duties to perform as specified in other sections of this HSP, or in Company procedures and manuals. 


\subsubsection{Occupational Medical Program}

The INEL OMP provides medical surveillance for personnel assigned as hazardous waste site workers per the OSHA standard. The OMP is also responsible for evaluation of personnel injured or exposed to hazardous materials at the task site. (See Section 4 for details of the medical surveillance program.)

\subsubsection{Quality Engineer}

The quality engineer provides guidance on task quality issues when requested. The quality engineer observes task site activities and verifies that task operations comply with quality requirements pertaining to these activities. The quality engineer identifies activities that do not comply or that have the potential for not complying with quality requirements, and suggests corrective actions.

\subsubsection{TRA Landlord}

The TRA landlord will be kept informed of all activities and will serve as advisor to the excavating and sampling crew with regard to TRA. In case of an emergency, the TRA landlord will be notified and will act as coordinator of the situation in regards to the TRA facilities and facility personnel actions.

\subsection{Recordkeeping Requirements}

\subsubsection{Industrial Hygiene and Radiological Monitoring Records}

The IH will record air monitoring and personnel sampling data on Form EG\&G-737, "Industrial Hygiene Monitoring Data Form." IH monitoring data are treated as limited access information and are maintained by the IH per the Company Procedures Manual, Section 11.14, "Management of Industrial Hygiene Monitoring Records." The RCT will document all radiological monitoring and surveys in accordance with Section 10, Vol. VI of the EG\&G Idaho Company Procedures Manual. The RCT shall document daily operational activities on the RADCON-Daily Log Sheet, Form EG\&G924 in accordance with Section 10.13, Maintaining the Radiological Control Logbook, Vol VI of the EG\&G Idaho Company Procedures Manual. The RCT shall ensure all instrument calibrations and performance checks are performed and documented in accordance with Section 10, Vol. VI of the EG\&G Idaho Company Procedures Manual. Radiological monitoring records are maintained according to the EG\&G Idaho Radiological Controls Manual, Chapter 7, "Radiological Records." Verification of the completion of radiological action/hold point steps shall be documented and maintained in the appropriate job specific technical work control document.

\subsubsection{FTL Logbook and Site Attendance Logbook}

The FTL will keep a record of daily task site events in the FTL logbook. The FTL is also responsible for maintaining an accurate record of all personnel (workers, and nonworkers) who are on site each day in a site attendance logbook. These logbooks must be submitted to the document control office along with other documents at the end of the project. 


\subsubsection{Document Control Office}

The document control office is responsible for organizing and maintaining data and reports generated by ERP field activities. The document control office maintains a supply of all controlled documents and provides a documented system for the control and release of controlled documents, reports, and records. Copies of the Management Plans for the Environmental Restoration Program, this HSP, the Quality Program Plan for the Environmental Restoration Program (QPP-149), and other documents pertaining to this task are maintained in the project file by the document control office. All project records and logbooks, except IH and RCT records, must be forwarded to the document control office within 30 days after completion of field activities. 


\section{PERSONNEL TRAINING}

All task site personnel will receive training as specified by OSHA 29 CFR 1910.120 and the Company Procedures Manual, Section 1.11, "Identification of Training Requirements." Radiation worker training shall be in accordance with the EG\&G Idaho Radiological Controls Manual, Chapter 6, "Training and Qualification" and Volume VI of the EG\&G Idaho Company Procedures Manual, "General Employee Radiological Training" and "Radiological Workers Training." Table 1 summarizes training requirements for task site personnel. Specific training requirements for each worker may vary depending on the hazards associated with the job assignment.

Proof of completion of all required training courses (including refresher training) must be maintained on the site at all times. Examples of acceptable written training documents include, EG\&G IDF-5483.C, "40 Hour OSHA HAZWOPER Card," EG\&G-2533, "Respirator Authorization Card," DOE Certificate of Core Radiological Training I or II Card," "Medic First Aid Training Card," and/or a copy of an individual's Training Inquiry System (TIS) printout demonstrating completion of training. A copy of the certificate issued by the institution where the training was received is also acceptable proof of training.

Before beginning work at the task site, a project safety orientation will be conducted by the FTL and JSS. The orientation will consist of a complete review of this HSP and attachments, with time for discussion and questions. At this time, personnel training will be checked and verified to be current and complete for all required training shown in Table 1. Upon completing the safety orientation, personnel will sign the training acknowledgement form (Section 12 of this HSP) to indicate that they have received the briefing and understand the HSP. 
Table 1. Required training for task site personnel.

\begin{tabular}{|c|c|c|c|c|}
\hline Task/position & FTL/JSS & Task team & $\begin{array}{c}\text { IH/RCT/ } \\
\text { safety } \\
\text { engineer/rad } \\
\text { engineer }\end{array}$ & Nonworkers \\
\hline Topic & Required & Required & Required & Required \\
\hline Task site orientation & $\mathrm{X}$ & $\mathrm{X}$ & $\mathrm{X}$ & $\mathrm{X}$ \\
\hline Decontamination $^{2}$ & $X$ & $X$ & $\mathrm{X}$ & $X^{b}$ \\
\hline Hazard communication ${ }^{a}$ & $X$ & $\mathrm{X}$ & $\mathrm{X}$ & $X$ \\
\hline Site control and warning devices ${ }^{a}$ & $\mathrm{X}$ & $\mathrm{X}$ & $X$ & $\mathrm{X}$ \\
\hline $\begin{array}{l}\text { Emergency action plan for task } \\
\text { site }^{\mathrm{a}}\end{array}$ & $\mathrm{X}$ & $\mathrm{X}$ & $X$ & $\mathrm{X}$ \\
\hline OSHA hazardous waste operator & $X$ & $X$ & $\mathrm{X}$ & $X$ \\
\hline OSHA hazardous waste supervisor & $\mathrm{X}$ & 一 & - & - \\
\hline Hearing conservation ${ }^{d}$ & $X$ & $\mathrm{X}$ & $X$ & $X$ \\
\hline Radiation worker qualification ${ }^{d}$ & $\mathrm{X}$ & $\mathrm{X}$ & $\mathrm{X}$ & $X$ \\
\hline Medic First ${ }^{e}$ & $\mathrm{X}$ & $\mathrm{X}$ & - & - \\
\hline Respirator qualification and fit test ${ }^{f}$ & $\mathrm{X}$ & $\mathrm{X}$ & $\mathrm{X}$ & $X$ \\
\hline Confined Space Entry Certified ${ }^{\mathrm{g}}$ & $\mathrm{X}$ & $\mathrm{X}$ & $\mathrm{X}$ & - \\
\hline
\end{tabular}


a. Will be included in task site orientation.

b. If entering contaminated areas.

c. Includes 40 hours of classroom and 24 hours of field experience for the FTL, JSS, and appropriate members of the task team. Includes 24 hours of classroom and 8 hours of field experience for the remaining individuals.

d. As appropriate.

(RW-I, RW-II, GERT)

e. Two Medic First qualified individuals must be present during site activities.

f. If entering areas requiring respirator use.

g. If confined space entry is required. 


\section{OCCUPATIONAL MEDICINE PROGRAM AND MEDICAL SURVEILLANCE}

Task site personnel shall participate in the INEL OMP per the requirements of OSHA 29 CFR 1910.120, which requires medical surveillance examinations prior to assignment, annually, and after termination of hazardous waste duties. This includes employees who are or who may be exposed to hazardous substances at or above published exposure limits, without regard to respirator use, for 30 or more days per year, as well as those who wear a respirator for 30 or more days per year. Employees who must use a respirator in their job or who are required to take training to use a respirator to perform their duties under this plan must be medically evaluated for respirator use at least annually. Job-related information must be provided to the OMP for each hazardous material worker via completion of Form EG\&G-735, "Notification of Employee Exposure and Personal Protective Equipment Use to INEL OMP." This information must be submitted to the OMP before work begins. Information to the OMP must be supplemented or updated annually using this same form, as long as the employee is required to maintain hazardous waste/hazardous material worker medical clearance.

The OMP is responsible for evaluating the physical ability of a worker to perform the task assigned, and provides medical clearance to the worker for the work to be performed. The OMP may impose restrictions on the employee by limiting the amount or type of work performed.

Areas addressed by the OMP for hazardous waste site workers include:

- Current comprehensive medical examinations in an INEL medical facility for full-time employees

- Records and reports from employees' private physicians, as required by the site occupational medical director

- Medical evaluation by the OMP on return to work following an absence in excess of one work week (40 consecutive work hours) resulting from illness or injury

- Medical evaluation in the event that a supervisor questions the ability of an employee to work

- Medical evaluation in the event that an employee questions their own ability to work.

The information provided on the forms and by employee examination are used to determine the following for each employee:

- Ability to perform relevant occupational tasks

- Ability to work in protective equipment and heat stress environments 
- Ability to use respiratory protection

- Entry into substance-specific medical surveillance programs.

Results of the following tests shall be made available to the OMP when any abnormal radiological exposure is noted or a radiological contamination incident occurs:

- Whole body count (baseline, annual, and on actual or suspected radiological contamination incident)

- Bioassay (baseline, as required to assess internal radiation dose, and on actual or suspected radiological contamination incident).

\subsection{Subcontractor Workers}

Medical data from the worker's private physician, collected pursuant to hazardous material worker qualification of a subcontractor worker, shall be made available to the OMP upon request. Also, subcontractor workers' past radiation exposure histories must be submitted to the Operational Dosimetry Unit of EG\&G Idaho, per the EG\&G Idaho Radiological Controls Manual, Chapter 2, "Radiological Standards." Subcontractor workers shall provide the FTL with proof of training as specified in Section 3 of this HSP.

\subsection{Injuries on the Task Site}

It is the policy of the OMP to examine all workers, including subcontractors, if the workers are injured on the job, if they are experiencing symptoms consistent with exposure to a hazardous material, or if there is reason to believe that they have been exposed to toxic substances or physical agents in excess of allowable limits.

In the event of a known or suspected injury or illness due to exposure to a hazardous substance or physical agent, the worker(s) shall be transported to the nearest medical facility for evaluation, with as much information as possible regarding the suspected cause of injury or illness. As much of the following information as is available will accompany the individual to the medical facility:

- Name, job title, work location, and supervisor's name and phone number

- Substances or physical agents (known or suspected); material safety data sheet (MSDS) if available

- Date of employee's first exposure to the substance or physical agent

- Locations, dates, and results of exposure monitoring

- $\quad$ PPE in use during this task (for example, respirator and cartridge)

- Number of days per month PPE has been in use 
- $\quad$ Anticipated future exposure to the substance or agent.

Further medical evaluation will be in accordance with the symptoms, hazard involved, exposure level, and specific medical surveillance requirements. If personnel are injured while within a radiological control area (with a potential for contamination), notification of the RCT is required. The RCT shall monitor all open wounds to determine if contamination is present. It should be noted that contamination (alpha and low energy beta) can be shielded by the fluids from the wound and/or the wound itself. The RCT should escort the injured individual to the medical facility even if the individual is only potentially contaminated. The health of the individual will always have priority over radiological concerns. Personnel who obtain a wound within a radiological controlled area (with the potential for contamination) shall participate, as deemed necessary, in the bioassay monitoring program.

\subsection{Substance-Specific Medical Surveillance}

Substance-specific medical surveillance requirements that may apply to personnel working at the task site are 29CFR1910.1001 for asbestos, and 29CFR1910.1025 for lead. 


\section{SAFE WORK PRACTICES}

\subsection{General Safe Work Practices}

The following are general safe work practices that will be followed at the task site:

- Do not wear contact lenses in designated eye-hazard areas unless they are essential to correct a vision defect not correctable by prescription safety glasses. Additional restrictions may apply per the EG\&G Idaho Safety Manual, Section 7, "Personal Protective Equipment."

- Absolutely no eating, drinking, chewing gum or tobacco, smoking, applying cosmetics, or any other practice that increases the probability of hand-to-mouth transfer and ingestion of materials except in designated areas.

- Report all broken skin or open wounds to the JSS or FTL. The OMP will determine if the wound presents a significant risk of internal chemical or radiological exposure. The OMP evaluation will consider how the wound is bandaged and will recommend PPE to be worn by the injured employee. Personnel with unprotected wounds shall not be permitted to enter contamination areas, nor shall they handle contaminated or potentially contaminated materials at the site.

- Avoid direct contact with potentially contaminated substances. Do not walk through spills or other areas of contamination. Avoid kneeling, leaning, or sitting on equipment or ground that may be contaminated.

- Be alert for dangerous situations, strong or irritating odors, airborne dusts or vapors, and broken containers. Report all potentially dangerous situations to the FTL or JSS.

- Prevent releases of hazardous materials, including those used at the task site. If a spill occurs, contain it (if possible), evacuate the area, and report it to the FTL or JSS. Response actions to radiological spills shall be performed in accordance with Section 10.26, Response Actions to Spills of Radioactive Material, of Vol VI of the EG\&G Idaho Company Procedures Manual. Guidelines for spill cleanup found in Appendix III of the EG\&G Idaho Company Procedures Manual, Section 11.6, "Carcinogen Control," may be useful. Appropriate spill kits, or other containment and absorbent materials, will be maintained at the work site. (See Section 10 of this HSP for more details on the spill response plan for the task site.)

- Keep all ignition sources at least $50 \mathrm{ft}$ from explosive or flammable environments, and use non-sparking, explosion-proof equipment if advised to do so by a safety professional.

- Be familiar with the physical characteristics of the task site, including, but not limited to:

- Wind direction 
- Accessibility of fellow workers, equipment, and vehicles

- Communications at the task site and with other nearby facilities

- Areas of known or suspected contamination or airborne radioactivity

- Major roads and means of access to and from the task site

- Nearest water sources and fire-fighting equipment

- Warning devices and alarms

- Capabilities and location of nearest emergency assistance.

- If you are working in a contamination area, work in teams according to the "buddy system" (see Section 5.3 of this HSP).

- Proceed directly to a survey station upon leaving a contamination, high contamination, or airborne radioactivity area and associated radiological buffer areas. Care should be taken not to touch the face, mouth, or eyes before a survey has been performed. Notify radiological control personnel when contamination is found.

\subsection{ALARA Principles}

Personnel working at the task site must strive to keep radiation exposure ALARA through the following practices:

- Adhere to all written radiological requirements and verbal guidance

- Adhere to radiological work permit requirements

- Obey "Evacuate" and "Stop Work" orders from radiological control personnel promptly

- Notify radiological control personnel of alarming or faulty radiological control equipment

- $\quad$ Be aware of personal radiation exposure history

- Work within ALARA guidelines and make suggestions as needed

- Minimize the production of all radiological waste

- Place contaminated tools, equipment and solid waste items on disposable surfaces, such as plastic sheets, when not in use 
- Minimize personal radiation exposure by adhering to these basic protection techniques:

- $\quad$ Time-Exposure is minimized as time is minimized

- Distance-Maintain a maximum distance from the radiation source

- Shielding-Use any solid material (such as lead, steel, or concrete) as a shield

\subsection{The Buddy System}

The buddy system will be used at the task site to ensure that each worker's mental and physical well-being is monitored during the course of the day. Task site personnel will be assigned a "buddy" by the FTL to work with and reguiarly check on during the day. Workers need to be able to see or hear and effectively communicate with their buddy at all times when in the contamination area. Everyone should watch for signs and symptoms of illness or injury in their assigned "buddy." 


\section{SITE CONTROL AND SECURITY}

\subsection{Contamination Area}

Contamination areas include the following buildings or areas: TRA-611, MTR plug storage; TRA-612, MTR retention basin sump pump house; TRA-642, ETR reactor building; TRA-643, ETR compressor building; TRA-644, ETR heat exchanger building; TRA-647, ETR office building; TRA704, ETR primary filter pit; TRA-705, ETR secondary filter pit; TRA-706, ETR exhaust delay tanks; and TRA-755, ETR filter pit building. The contamination area boundary (exclusion zone) for the sampling activities will be established by the RCT for each area or facility in accordance with Section 10.10, Posting Radiological Control Areas, of Vol VI of the EG\&G Idaho Company Procedures Manual. Requirements for personnel access to contamination areas are described in the EG\&G Idaho Radiological Controls Manual, Chapter 3, "Conduct of Radiological Work," including postings, boundary establishment, and use of step-off pads at entry and exit points. All anti-C clothing and protective equipment for radiological control purposes shall be as specified by the job-specific Radiological Work Permit (RWP). The potential for the presence of radioactive contamination within the identified rooms requires that all personnel and equipment be surveyed with a hand-held survey meter upon leaving the contamination areas. All personnel shall also perform whole body monitoring by using the nearest PCM-1B monitor.

\subsection{Radiological Buffer Area}

The radiological buffer area (RBA) is established within the Controlled Area to provide a second boundary (contamination reduction zone) to minimize the spread of contamination. The RBA may serve as a temporary staging area for equipment and as a temporary rest area for workers. Because of the potential for contamination, PPE and sample packaging and preparation equipment should not be stored here. The RBA will be established by erecting temporary enclosures around the entrances to the contamination areas identified in Section 6.1. 


\subsection{Exclusion Zone}

The Exclusion Zone is established within the Controlled Area to provide a boundary to minimize the spread of contamination. The exclusion zone will be established by erecting temporary enclosures or installing rope barriers around the entrances to the contamination areas identified in Section 6.1.

\subsection{Contamination Reduction Zone}

The contamination reduction zone is established within the Controlled Area to provide a second boundary to minimize the spread of contamination. The contamination reduction zone may serve as a temporary staging area for equipment and as a temporary rest area for workers. Because of the potential for contamination, PPE and sample packaging and preparation equipment should not be stored here. The contamination reduction zone will be established by erecting temporary enclosures or placing rope barriers around the entrances to the work areas identified in Section 6.1.

\subsection{Support Area}

The support area is the area outside the RBA or contamination reduction zone. It contains the task control area, vehicle parking, additional equipment staging, and any task site support activities. The support area will be established at the TRA fence. Training acknowledgements and a controlled copy of this HSP shall be maintained in this area. After nonworkers have reported to the JSS, they shall report to this area. The area may also serve as a change room and some emergency equipment may be stored there. A map of the above areas is not shown, since the exact boundaries will be determined before starting work activities.

\subsection{Designated Eating Area}

Ingestion of hazardous substances is likely when workers do not practice good personal hygiene habits. It is important to wash hands, face, and other exposed skin thoroughly after completion of work and before smoking, eating, drinking, and chewing gum or tobacco. No smoking, chewing, eating, or drinking is allowed at the task site. An eating area will be designated to allow chewing, eating, and drinking. No modesty garments are allowed in the eating area. 


\section{HAZARD EVALUATION}

Personnel may be exposed to industrial safety hazards or physical agents while working at the task site. Table 2 summarizes each task and the associated hazards. Radiological hazards at the task site are outlined in Section 7.1. The radiological and industrial hygiene hazard monitoring plans are outlined in Section 7.2.

\subsection{Radiological Hazards}

The main areas of radiological and chemical contamination concern are the TRA-642 reactor building, TRA-643 compressor building, and TRA-645 secondary coolant pump house. The highest beta-gamma loose contamination levels will be experienced within the experiment cubicles. The maximum radiation levels will be in the warm waste tank pit under the warm waste tank. Chemical concerns will be chromates, nitric acid, and boric acid, which can be located in the compressor building (chemistry laboratory) and secondary coolant pump house (acid pit and pump pit) areas.

Task site activities involving known or potential radiological hazards will be controlled by job specific technical work control documents, in addition to this HSP and the Abbreviated Sampling and Analysis Plan (ASAP) for this project. These documents will provide the detailed planning and the necessary work control, including all work steps and radiological action and/or hold point steps. If the job specific potential working conditions require, an ALARA review shall be conducted with the necessary controls incorporated into the appropriate work control document for each work task and/or work location. The use of these documents will be supported by associated Radiological Work Permits (RWPs). The RWPs will specify the anti-c clothing and protective equipment requirements and any other entry requirements (such as dosimetry, stay times, etc.). It should be noted that no action and/or hold point steps will be included within the RWP. The conduct and control of radiological work operations shall be performed in accordance with the requirements of Chapter 3 , Conduct of Radiological Work, of the EG\&G Radiological Control Manual and Section 10, Vol VI, of the EG\&G Idaho Company Procedures Manual (Sections 10.9, 10.16, and 10.17).

\subsection{Environmental and Personnel Monitoring}

Personnel working at the task site may be exposed to hazardous materials or hazardous physical agents, as previously described. Industrial hygiene and radiological monitoring plans are described in Sections 7.2.1 and 7.2.2. Industrial safety hazards and other physical hazards will be monitored and controlled as outlined in Section 7.3.

\subsubsection{Industrial Hygiene Monitoring}

Specific hazardous agent exposures that will be monitored are indicated in Table 3 . The equipment listed in Table 4 may be used by the IH on the task site to monitor chemical and (nonradiological) physical agents.

All industrial hygiene equipment will be maintained by the IH per the manufacturer's

recommendations. Instruments will be calibrated before and after use, or according to the schedule 
outlined in the EG\&G Idaho Company Procedures Manual, Section 11.4, "Calibration of Industrial Hygiene Instruments."

Table 2. Task site activities and associated hazards.

\begin{tabular}{|c|c|c|c|c|}
\hline Location & $\begin{array}{c}\text { Activity } \\
\text { or } \\
\text { Task }\end{array}$ & $\begin{array}{l}\text { Associated } \\
\text { hazard(s) }\end{array}$ & $\begin{array}{l}\text { Sampling } \\
\text { Method }\end{array}$ & $\begin{array}{c}\text { PPE } \\
\text { Required }\end{array}$ \\
\hline TRA-611 & Obtain soil samples & Radiological & $\begin{array}{l}\text { Mechanical } \\
\text { Manual Auger }\end{array}$ & Class D \\
\hline TRA-612 & $\begin{array}{l}\text { Obtain sump } \\
\text { samples (liq \& } \\
\text { smears) }\end{array}$ & $\begin{array}{l}\text { Radiological, confined } \\
\text { space work area }\end{array}$ & $\begin{array}{l}\text { Hand Smears, } \\
\text { Bottle dipping, } \\
\text { manual } \\
\text { scraping }\end{array}$ & Class D \\
\hline TRA-642 & $\begin{array}{l}\text { Obtain smear } \\
\text { samples, tank } \\
\text { content samples, } \\
\text { concrete samples, } \\
\text { paint samples, drain } \\
\text { residue samples, } \\
\text { resin samples }\end{array}$ & $\begin{array}{l}\text { Radiological, hoisting \& } \\
\text { rigging, chemical, dust }\end{array}$ & $\begin{array}{l}\text { Hand Smears, } \\
\text { Mechanical } \\
\text { Extraction, } \\
\text { Bottle Dipping, } \\
\text { Manual } \\
\text { Scraping, } \\
\text { Concrete Core } \\
\text { Drilling, Oil } \\
\text { Draining }\end{array}$ & Class D \\
\hline TRA-643 & $\begin{array}{l}\text { Obtain smear } \\
\text { samples, oil } \\
\text { samples, drain } \\
\text { residue samples }\end{array}$ & $\begin{array}{l}\text { Radiological, chemical, } \\
\text { and PCBs }\end{array}$ & $\begin{array}{l}\text { Hand Smears, } \\
\text { Bottle Dipping, } \\
\text { Manual } \\
\text { Scraping, Oil } \\
\text { Draining }\end{array}$ & Class D \\
\hline TRA-644 & $\begin{array}{l}\text { Obtain smear } \\
\text { samples, tank } \\
\text { residue samples }\end{array}$ & Radiological & $\begin{array}{l}\text { Hand Smears, } \\
\text { Manual } \\
\text { Scraping }\end{array}$ & Class D \\
\hline TRA-645 & $\begin{array}{l}\text { Obtain smear } \\
\text { samples, drain } \\
\text { residue samples }\end{array}$ & $\begin{array}{l}\text { Chemical, PCBs, } \\
\text { confined space areas }\end{array}$ & $\begin{array}{l}\text { Hand Smears, } \\
\text { Manual } \\
\text { Scraping, } \\
\text { Manual Auger, } \\
\text { Oil Draining }\end{array}$ & Class D \\
\hline TRA-647 & $\begin{array}{l}\text { Obtain smear } \\
\text { samples, drain } \\
\text { residue samples, } \\
\text { material collection }\end{array}$ & $\begin{array}{l}\text { Radiological, lead, } \\
\text { chemical, PCBs }\end{array}$ & $\begin{array}{l}\text { Hand Smears, } \\
\text { Manual } \\
\text { Scraping, Oil } \\
\text { Draining, } \\
\text { Materials } \\
\text { Collection }\end{array}$ & Class D \\
\hline
\end{tabular}




\begin{tabular}{|c|c|c|c|c|}
\hline Location & $\begin{array}{c}\text { Activity } \\
\text { or } \\
\text { Task }\end{array}$ & $\begin{array}{l}\text { Associated } \\
\text { hazard(s) }\end{array}$ & $\begin{array}{l}\text { Sampling } \\
\text { Method }\end{array}$ & $\begin{array}{c}\text { PPE } \\
\text { Required }\end{array}$ \\
\hline 3TRA-648 & $\begin{array}{l}\text { Obtain smear } \\
\text { samples, petroleum } \\
\text { smear samples, } \\
\text { drain residue } \\
\text { samples }\end{array}$ & Chemical, PCBs & $\begin{array}{l}\text { Hand Smears, } \\
\text { Manual } \\
\text { Scraping }\end{array}$ & Class D \\
\hline TRA-655 & $\begin{array}{l}\text { Obtain smear } \\
\text { samples }\end{array}$ & $\begin{array}{l}\text { radiological, confined } \\
\text { space work area }\end{array}$ & Hand Smears & Class D \\
\hline TRA-663 & $\begin{array}{l}\text { Obtain smear } \\
\text { samples, petroleum } \\
\text { smear samples }\end{array}$ & Chemical, PCBs & $\begin{array}{l}\text { Hand Smears, } \\
\text { Manual } \\
\text { Scraping }\end{array}$ & Class D \\
\hline TRA-704 & $\begin{array}{l}\text { Obtain smear } \\
\text { samples }\end{array}$ & $\begin{array}{l}\text { Radiological, confined } \\
\text { space work area }\end{array}$ & Hand Smears & Class D \\
\hline TRA-705 & $\begin{array}{l}\text { Obtain smear } \\
\text { samples }\end{array}$ & $\begin{array}{l}\text { Radiological, confined } \\
\text { space work area }\end{array}$ & Hand Smears & Class D \\
\hline TRA-706 & $\begin{array}{l}\text { Obtain soil samples } \\
\text { from around the } \\
\text { area of the tanks }\end{array}$ & Radiological & Manual Auger & Class D \\
\hline TRA-755 & $\begin{array}{l}\text { Obtain smear } \\
\text { samples }\end{array}$ & Radiological & Hand Smears & Class D \\
\hline
\end{tabular}


Table 3. Contaminants.

\begin{tabular}{|c|c|c|}
\hline Area & Task or assignment & Potential Contaminant \\
\hline TRA-611 & Sampling, (Soil Collection) & Radiological Contamination \\
\hline TRA-612 & Sampling, (Smears, Liquid) & Radiological Contamination \\
\hline TRA-642 & $\begin{array}{l}\text { Sampling, (Smears, Residue, } \\
\text { Materials, Liquid, Oil Collection) }\end{array}$ & $\begin{array}{l}\text { Radiological Contamination, Radiation, Nitric } \\
\text { Acid, Boric Acid, Hazardous Concrete Dust, } \\
\text { PCBs }\end{array}$ \\
\hline TRA-643 & $\begin{array}{l}\text { Sampling, (Smears, Residue, } \\
\text { Liquid, Oil Collection) }\end{array}$ & $\begin{array}{l}\text { Radiological Contamination, Radiation, Nitric } \\
\text { Acid, Boric Acid, Sulfuric Acid, PCBs }\end{array}$ \\
\hline TRA-644 & Sampling, (Smears) & Radiological Contamination, Radiation \\
\hline TRA-645 & $\begin{array}{l}\text { Sampling, (Smears, Residue, } \\
\text { Liquid, Soil Collection) }\end{array}$ & Chromates, nitric acid \\
\hline TRA-647 & $\begin{array}{l}\text { Sampling, (Smears, Residue, } \\
\text { Materials, Liquid) }\end{array}$ & Radiological Contamination, Lead, PCBs, \\
\hline TRA-648 & Sampling, (Smears, Residue) & $\begin{array}{l}\text { Radiological Contamination, Sulfuric Acid, } \\
\text { PCBs }\end{array}$ \\
\hline TRA-655 & Sampling, (Smears) & Radiological Contamination \\
\hline TRA-663 & Sampling, (Smears, Residue) & PCB's \\
\hline TRA-704 & Sampling, (Smears) & Radiological Contamination \\
\hline TRA-705 & Sampling, (Smears) & Radiological Contamination \\
\hline TRA-706 & Sampling, (Smears) & Radiological Contamination \\
\hline TRA-755 & Sampling, (Smears) & Radiological Contamination \\
\hline
\end{tabular}

Table 4. Equipment that may be used for monitoring.

\begin{tabular}{ll}
\hline \multicolumn{1}{c}{ Equipment } & Agent to be monitored \\
\hline Personal sampling pumps and appropriate media & Organic vapors, metals, dusts \\
Heat stress monitor (wet bulb globe temperature) & Heat stress conditions \\
\hline
\end{tabular}


Table 5. Hazardous materials present at TRA.

\begin{tabular}{|c|c|c|c|c|c|c|}
\hline $\begin{array}{l}\text { Hazardous } \\
\text { material name } \\
\text { and CAS } \\
\text { number }\end{array}$ & $\begin{array}{l}\text { Exposure } \\
\text { limit' } \\
\text { (PEL/TLV/R } \\
\text { EL) }\end{array}$ & $\begin{array}{l}\text { Routes of } \\
\text { exposure }\end{array}$ & $\begin{array}{l}\text { Symptoms of } \\
\text { overexposure }^{c}\end{array}$ & Target organs/systems & $\begin{array}{c}\text { Carcinogen? } \\
\text { (source) }^{\mathrm{d}}\end{array}$ & $\begin{array}{c}\text { Expected } \\
\text { levels }\end{array}$ \\
\hline $\begin{array}{l}\text { Cadmium, } \\
7440-43-9\end{array}$ & 0.01 & Ih, Ig & RESP,CNS & $\begin{array}{l}\text { RespSys, kidneys, } \\
\text { prostate, blood }\end{array}$ & Yes, ACGIH A2 & $? ?$ \\
\hline $\begin{array}{l}\text { Lead, 7440-92- } \\
1\end{array}$ & 0.05 & Th, Ig,S & EYES,CNS & $\begin{array}{l}\text { GI tract, CNS, } \\
\text { kidneys, blood, } \\
\text { Gingivival tiss }\end{array}$ & Yes, ACGIH A3 & $? ?$ \\
\hline $\begin{array}{l}\text { Nuisance dust } \\
\text { or fumes }\end{array}$ & NA & Ih & EYES,RESP & skin, eyes & - & Minimal \\
\hline \multicolumn{7}{|c|}{$\begin{array}{l}\text { a. most recent vaiues. PEL - permissible exposure limit, REL - recor } \\
\text { b. (Th) inhalation; (Ig) ingestion; (S) skin absorption. }\end{array}$} \\
\hline \multicolumn{7}{|c|}{$\begin{array}{l}\text { c. (NS) dizziness/nausea/lightheadedness; (DERM) rashes/itching/redness; (RESP) respiratory effects; (EYES) tearing/irritation; (CNS) } \\
\text { central nervous system; (O) other symptoms-must be specified. }\end{array}$} \\
\hline
\end{tabular}

Air sampling, if determined necessary, will be conducted using NIOSH or OSHA methods, and according to the EG\&G Idaho Company Procedures Manua7, Section 11.5, "Industrial Hygiene Air Contaminant Sampling Procedure." Samples will be personal samples whenever possible; each non-radiological contaminant or agent listed in Table 3 will be monitored. The number and frequency of sampling will depend on the IH's assessment of potential exposures and risk assessment for task site personnel, in accordance with EG\&G Idaho Company Procedures Manual, Section 11.9, "Industrial Hygiene/Workplace Surveys." Sampling data, results from direct-reading instruments, and field observations will be recorded on Form EG\&G-737, "Industrial Hygiene Data Monitoring Form," and entered into the IH database, System 80.

\subsubsection{Radiological Monitoring}

The potential radiological conditions at the task site are identified in Section 7.1. Contamination and radiation surveys and airborne radioactivity monitoring shall be performed by an RCT, as specified by the appropriate technical work control document. These surveys and monitoring sha17 be performed to verify work area conditions and condition boundaries. RCTs shall also survey and tag material/waste/equipment and ensure it is properly contained prior to removal from designated Contamination Areas and Radiological Buffer Areas.

The RCT will be responsible for radiological monitoring in accordance with the EG\&G Idaho Radiological Controls Manual, Chapter 5, "Radiological Health Support Operations, "and Chapter" 7, "Radiological Records"; and the EG\&G Idaho Company Procedures Manual, Section 10, "Radiological Control Procedures." All radiological control equipment shall be cal ibrated and 
performance checked in accordance with Section 10, Vol VI of the EG\&G Idaho Company Procedures Manual (Section 10.6).

The equipment listed in Table 5 (or equivalent) may be used to monitor radiological contamination on site. These instruments are examples of instruments that may be used at the task site. The use of instruments is not limited to this list. 
Table 6. Radiological monitoring equipment.

\begin{tabular}{ll}
\hline \multicolumn{1}{c}{ Equipment } & Monitoring use \\
\hline Ludlum 2a with pancake probe & Beta-gamma \\
Ludlum 61 or Eberline Pac-4s & Alpha \\
Personal sampling pumps & Lapel monitoring \\
\hline
\end{tabular}

Personnel Radiological Exposure Monitoring. In order to evaluate exposure to ionizing radiation, all task site personnel will be required to wear thermoluminescent dosimetry (TLDs) at the task site. Additional dosimetry, as specified by the appropriate RWP, may be required to access certain task site locations. Sampling pumps (lapel samplers), as specified by the appropriate RWP, may be required to be worn by personnel to access certain task site locations. Initial or annual bioassay monitoring, as a minimum, is required for task site access to radiologically controlled areas. All subcontracted personnel shall complete termination bioassay monitoring, upon termination or completion of work assignment at TRA.

\subsection{Physical Hazards Evaluation, Control, and Monitoring}

The physical hazards present at the task site, and the methods that may be used to monitor and control them, are described in the following paragraphs.

\subsubsection{Temperature Extremes}

Heat Stress. Workers may be required to wear protective clothing that prevents the body from cooling. High body temperatures can result in heat fatigue, physical discomfort, and death. Personnel must inform the FTL or JSS if they experience any of the signs or symptoms of heat stress, or observe that their work buddy is experiencing these symptoms. EG\&G Idaho Company Procedures Manual, Section 11.10, "Temperature Extremes," discusses the hazards of heat stress.

Monitoring for heat stress conditions may be performed by the IH according to the Company Procedures Manual, Section 11.10, and the Industrial Hygiene Manual, Section 20, "Temperature Extremes." Depending on the work conditions and physical response of task operations personnel, the IH will inform the JSS and FTL of necessary adjustments to the work/rest cycle. A supply of cool drinking water will be provided at the task site and consumed only in the designated eating area.

Workers may be periodically interviewed by the IH to ensure that the controls are effective and that excessive heat exposure is not occurring. Workers will be encouraged to monitor their body signs and to take a break if symptoms of heat stress occur. The signs of heat stress are:

- Clammy skin

- Dizziness or nausea

- Fatigue

- $\quad$ Profuse sweating

- Skin color change

- Vision problems. 
Individuals showing any of the symptoms listed above will stop work, rest, be provided cool drinking water, and be monitored by a Medic First qualified person. If personnel exhibiting symptoms of heat stress do not show signs of recovery when removed to the rest area, they will be transported to the dispensary for medical attention.

Heat stroke is an extremely serious condition that can result in death and should be treated as such. An individual who stops sweating, or who shows symptoms of confusion, slurred speech, or any other evidence of change in level of consciousness, will be transported IMMEDIATELY to the nearest medical facility for evaluation.

Cold Stress. Exposure to low temperatures may be a factor if work is done in the winter months, or at any time of year if the conditions are right. Relatively cool ambient temperatures, and wet or windy conditions increase the potential for cold injury to personnel. Section 11.10 of the EG\&G Idaho Company Procedures Manual discusses the hazards of cold stress. The IH will monitor cold stress conditions in accordance with Section 11.10 of the Company Procedures Manual, and Section 20 of the Industrial Hygiene Manual.

\subsubsection{Industrial Safety Hazards}

The EG\&G Idaho Safety Manual, Supplement 2.2 "Safe Work Permits (SWPs)/Special Safe Work Permits (SSWPs)," will be followed for all work performed involving the following safety hazards.

Personal Protective Equipment. Wearing PPE will reduce a worker's ability to move freely, see clearly, and hear directions and noise that might indicate a hazard. Also, PPE can increase the risk of heat stress. Work activities at the task site will be modified as necessary to ensure that personnel are able to work safely in the PPE that is required.

Elevated Work Areas. When performing certain task site activities (see Table 2), personnel will be required to work on elevated equipment or at heights. Fall protection requirements start at 6 feet. When such work is performed, personnel will use a harness and lanyard, or a safety net (for work at heights exceeding $25 \mathrm{ft}$ ) per Section 7 of the EG\&G Idaho Safety Manual. Personnel required to use fall-protection PPE shall be trained in its proper use, limitations, and how to maintain and inspect the equipment.

Handling Heavy Objects. Operations personnel may risk injury by lifting heavy objects. All operations personnel are therefore cautioned against lifting objects that are too heavy. Mechanical and hydraulic assists will be used whenever possible to minimize lifting dangers.

Decontamination. The chemical and radiological decontamination processes used to remove contaminants from tools, equipment, and task site personnel can spread contamination and increase the risk of exposure if decontamination activities are not performed according to procedures. Decontamination procedures must be followed and appropriate PPE must be used during decontamination activities.

Inclement Weather. In the event that adverse weather conditions develop that pose a threat to persons or property on the task site, such as sustained strong winds ( $25 \mathrm{mph}$ or greater), electrical storms, heavy precipitation, or extreme heat or cold, the situation will be evaluated by the FTL and JSS with input from the IH, safety engineer, RCT, radiological engineer, and other personnel, as appropriate. A decision to stop all work at the task site will be made by the FTL with input from the $\mathrm{IH}, \mathrm{RCT}$, and JSS based on the hazards involved and the situation. In some cases, work at the site 
may proceed provided that workers are afforded adequate, appropriate protection. At no time will individual health and safety be jeopardized in order to continue work.

\section{3 . 3 Confined Spaces}

Work in confined spaces may subject workers to risks involving engulfment, entrapment, oxygen deficiency and toxic or explosive atmospheres. There are confined spaces present at the task site; all entrances are posted with the required danger sign per the EG\&G Idaho Company Procedures Manual, Section 11.3, Appendix I. Confined spaces that personnel will enter at the task site include, TRA-612 Confined Space \#183 or \#166, The Retention Basin Sump Area; TRA-645 Confined Space \#114, Secondary Coolant Piping Trench; and TRA-655, Confined Space \#188, Experiment Air InTake Building. Personnel will be obtaining smears and/or liquid samples from the equipment located in the confined spaces. Confined spaces will be evaluated by an IH or safety engineer per the EG\&G Idaho Company Procedures Manual, Section 11.3, prior to anyone entering the space. A copy of the Form EG\&G-556, "Confined Space Identification and Evaluation Form" for each confined space to be entered will be provided HSO and project $\mathrm{IH}$. The evaluation will include completion of Form EGG1150, "Confined Space Entry Permit." - A trained attendant will be outside the space to assist entrants, monitor the well-being of entrants, and notify the rescue team, if necessary. Personnel required to enter the space will be thoroughly briefed on the hazards involved, the meaning of warning signals of any monitoring equipment that is worn or taken into the space, any special tools or equipment to be used, and actions to take in case of an emergency. The emergency rescue plan is outlined below.

Confined Space Emergency Rescue Plan. All confined space training will be verified by the Job Entry Supervisor (JES) and FTL. The entrant(s)/attendant(s) and JES must have course codes that meet the requirements listed in Section 3, "Personnel Training," Table 1. An emergency rescue plan must be specified; the rescue plan must be specific to the space(s) entered and the hazards involved. It must include the number and type of rescue equipment (for example, harnesses, lanyards, tripod/winch) that will be used by entrants and/or maintained at the site, where the equipment will be staged or set up to facilitate a rescue, and specific assignments for task site personnel who will participate in a rescue.

\subsection{Other Task Site Hazards}

Task site personnel should look for potential hazards and immediately inform the FTL or JSS of the hazards so that action can be taken to correct the condition. The FTL and JSS will conduct daily inspections of the task site to ensure that barriers and signs are being maintained, unsafe conditions are corrected, and debris is not accumulating on the site. These inspections will be noted in the FTL logbook. Health and safety professionals present at the task site may, at any time, recommend changes in work habits to the JSS or FTL. Individuals working at the task site are responsible to use safe work techniques, report unsafe working conditions, and exercise good personal hygiene and housekeeping habits throughout the course of their job. 


\section{PERSONAL PROTECTIVE EQUIPMENT}

PPE that will be used at the task site was selected based on the toxicity and anticipated levels of known or suspected hazardous materials and agents (including radiological hazards) at the task site, recommendations contained in NIOSH (1985), and on the hazard analysis in Section 7 of this HSP. Based on the hazard analysis and the recommendations cited above, Level D PPE with additional anti-contamination clothing is appropriate for the protection of personnel working at the task site. All protective equipment and clothing for protection against radiological hazards shall be as specified by the appropriate RWP. Level D protection is not appropriate protection against airborne hazards generated by certain sampling techniques (i.e. chiseling, sampling lead laden filters; handling liquid waste products). Additional Full Body protection and respiratory protection is warranted for these operations and will be specified in the appropriate work control documents.

Level D PPE affords little protection against chemical hazards and is appropriate for use at the task site since personnel are not expected to be exposed to hazardous chemicals above an allowable limit and no danger exists from absorption of chemicals through the skin. This level of PPE that is required at the task site consists of:

- Eye protection (see Section 7 of EG\&G Idaho Safety Manual)

- Hard hat

- Steel-toed boots as described in Section 7, Appendix III, of the EG\&G Idaho Safety Manual

- Hearing protection (as appropriate)

- Shoe covers, modesty garments, and anti-contamination clothing

If respirator use is determined to be necessary by the IH or RCT, all personnel required to wear respirators must have been trained and acceptably fit-tested for the assigned respirator, per the training and documentation requirements in Section 3 of this HSP. Requirements for respirator use, emergency use, storage, cleaning, and maintenance, as stated in the EG\&G Idaho Company Procedures Manual, Section 11.1, "Respiratory Protection Program Procedures," will be followed.

Table 6 lists each task or assignment and the corresponding level of PPE, as well as any additional or special items necessary for personal protection at the task site.

Table 6. Level of PPE and modifications for specific tasks.

Task or assignment

Perform drain sampling

Perform sampling
Level of PPE

D

D
Modifications

Latex gloves over nitrile rubber ( $N-D e x$ liners)

Appropriate gloves 


\section{DECONTAMINATION PROCEDURES}

Anti-contamination clothing must be removed in accordance with the posted instructions or as directed by the RCT at the site, and placed into the appropriate labeled container(s). All personnel shall proceed to a survey station and perform a whole-body survey upon exiting a contamination area; the survey will take two to three minutes.

Skin contamination should be reported immediately to the JSS. Radiological decontamination of personnel shall be done under the direct supervision of a radiological engineer or RCT in accordance with Chapter 5 of the EG\&G Idaho Radiological Controls Manual and with the EG\&G Idaho Company Procedures Manual, Section 10.4, "Decontamination of Personnel and Personal Property." Personnel and personal property decontamination procedures that may be used include: tape, vacuuming (vacuum must be equipped with a high-efficiency particulate air filter), washing with soap and water, or other approved techniques. All decontamination operations for equipment and areas shall be performed in accordance with the EG\&G Idaho Radiological Controls Manual, Chapter 4, "Radioactive Materials."

\subsection{Decontamination in Medical Emergencies}

If a person is injured or becomes ill, the situation will be evaluated by first aid personnel on the task site. Emergency care will be initiated and emergency preparedness procedures for the facility at which the task is being performed will be activated. Medical care for serious injury or illness will not be delayed for decontamination. In such cases, gross contamination may be removed by removing the injured person's outer protective gear (if possible). Additional decontamination may be performed at the medical facility. The IH or RCT (depending on the type of contamination) should accompany the employee to the medical facility to provide information and decontamination assistance to medical personnel. Chapter 5 of the EG\&G Idaho Radiological Controls Manual contains information on proper handling of radiologically contaminated wounds.

\subsection{Equipment Decontamination and Disposal}

Appropriate smear surveys, direct scans, or large area wipes will be used to determine if any radiological contamination is present on equipment and materials, if the contamination is loose or fixed, and the amount present. All equipment and material will be surveyed, using a hand-held frisker probe, for radiological contamination prior to leaving the site. Items will be considered contaminated if they are greater than $100 \mathrm{cpm}$ above background for beta-gamma contamination, or if there is any detectable alpha contamination. Items will be decontaminated if possible using wiping techniques, vacuuming with high-efficiency particulate air vacuums, or other methods recommended by the RCT or radiological engineer. Any aqueous solutions that are generated in the decontamination process will be minimized as much as possible and containerized to prevent the spread of contamination. All waste will be surveyed by the RCT and disposed of accordingly; liquids will be solidified in clay absorbent before disposal. All waste generated as a result of sampling will be managed and disposed of by D\&D Projects.

\subsection{Site Sanitation and Waste Minimization}

Task site personnel will use toilet facilities located outside the fenced area. Potable water and soap will also be available at the site for personnel to wash their hands and face upon exiting the work area. It is important to note that any required radiological contamination surveys must be performed before washing face and hands to prevent accidental spread of contamination. 
Waste materials will not be allowed to accumulate at the task site. Appropriate containers for contaminated and non-contaminated waste will be maintained at step-off areas, in the support zone, and at other appropriate locations at the task site. All waste will be surveyed by the RCT prior to removal from the task site. Personnel should make every attempt to minimize waste through judicious use of consumable materials. All task site personnel are expected to make good housekeeping a priority at the job site. 


\section{EMERGENCY RESPONSE PLAN FOR TASK SITE}

All task site personnel shall use the following emergency responses when necessary:

- The applicable methods and signals that will be used to alert task site personnel to stop work and evacuate buildings are TRA Evacuation System signals, radiation area monitor (RAM) alarms, constant air monitor (CAM) alarms, or the actions of individual employees. Personnel should evacuate to the appropriate staging area of TRA or to an area away from the RAM or CAM, or to an area designated by the RCT, FTL, or JSS.

- The take-cover location where personnel will assemble in the event of a take-cover alarm is the basement of TRA-603.

- In the event of a TRA site-wide evacuation siren, personnel at the task site will evacuate to the designated staging area. The FTL or JSS will account for all personnel and report to the TRA evacuation director. Personnel will board buses in accordance with the TRA evacuation procedures.

- The method task site personnel will use for summoning emergency assistance to the task site is to call 777, the Advanced Test Reactor (ATR) shift manager (533-4353), or the TRA landlord (533-4423).

Responsibilities at the task site during an emergency event are as provided in Table 7.

Table 7. Responsibilities during an emergency.

\section{Responsible person}

Task site personnel

FTL

First aid personnel

FTL

Task site personnel

Task site personnel
Action assigned

Signal evacuation

Call 777, ATR shift manager, or TRA landlord

First aid to victims

Contact OMP

Spill containment

Spill reporting 
At least two persons with current Medic First training will be present at the task site to render first aid assistance to victims in an emergency.

Radiological contamination in uncontrolled areas is considered a "spill." Spill control at the task site will be handled by task site personnel if the spills are small enough to be safely contained at the site. If any uncontrolled release of radioactive material is noticed, task site personnel will initiate the SWIMS approach:

- Stop the spill using appropriate measures

- Warn area personnel

- Isolate the area

- Minimize exposure to the spill

- Secure any ventilation paths and ensure that an RCT surveys the area to determine the extent of a radiological material spill.

In the case of a radioactive spill that cannot be contained by task site personnel, or a spill of a hazardous material, the FTL will contact the TRA landlord and/or ATR shift manager.

\subsection{Emergency Equipment on the Site}

Emergency response equipment that will be maintained at the task site includes:

- A fire extinguisher (minimum $15-\mathrm{lb} \mathrm{ABC}$ ) will be located at the ETR office building (TRA-647) and inspected monthly

- A first aid kit will be located at the ETR office building and inspected daily

- A radiological spill kit will be stored in the ETR office building and maintained by the RCT

- A portable eye wash station will be located in an accessible location and be conspicuously posted.

The INEL Fire Department, located at CFA-666, is the closest fire response facility. The TRA maintains an Emergency Response Brigade, which can be summoned through the ATR shift manager and will respond until the fire department can arrive. The INEL Fire Department also maintains a hazardous material van equipped to respond to an emergency involving the release of a hazardous material.

\subsection{Telephone/Radio Contact Reference List for TRA (ETR/MTR) Sampling}

This reference list will be posted near the telephone in the office trailer.

- Warning Communications Center (WCC)

- $\quad$ First Aid (TRA-667) 
- Occupational Medical Program (WCB Dispensary)

- Fire

- Security

- Explosives expert - Richard Green

$526-2702$

- Hazardous Materials Team (HAZMAT) - CFA Fire Department

$526-8457$

- $\quad$ Safety Engineer - M. T. Langlois

$526-2709$

- Industrial Hygiene - M. T. Langlois

$526-2709$

- Radiological Control - TRA-604

$3-4131$

- Radiological Engineering - TRA-678

$3-4221$

- Environmental Coordinator - H. G. Vega

$526-5807$

- $\quad$ Project Manager - D. E. Baxter

$526-5519$

- $\quad$ Field Team Leader - H. G. Vega

$526-5807$

- $\quad$ Sampling Field Team Leader - N. R. Ricks

$523-9552$

- Job Site Supervisor - J. Clayton

$526-2698$ 


\section{REFERENCES}

Company Procedures Manual, EG\&G Idaho, Inc., current issue.

Industrial Hygiene Manual, EG\&G Idaho, Inc., current issue.

Management Plans for the EG\&G Idaho Environmental Restoration Program, EG\&G Idaho, Inc., current issue.

NIŌSH, 1985, Occupational Safety and Health Guidance Manual for Hazardous Waste Site Activities, NIOSH/OSHA/USCG/EPA, DHHS (NIOSH) Publication No. 85-115, October.

Quality Program Plan for the Environmental Restoration Program, QPP-149, EG\&G Idaho, Inc., current issue.

Radiological Controls Manual, EG\&G Idaho, Inc., current issue.

Ricks, N. R., 1994, Abbreviated Sampling and Analysis Plan for Planning Decontamination and Decommissioning at Test Reactor Area (TRA) Facilities, EGG-ER-11504, Scientech, Inc., August 1994.

Safery Manual, EG\&G Idaho, Inc., current issue. 


\section{HEALTH AND SAFETY PLAN TRAINING ACKNOWLEDGEMENT}

The signatures below certify that:

- The employee has received a copy of the health and safety plan for the ETR/MTR sampling project and the plan has been reviewed with the employee

- The employee understands the hazards that are or may be involved in work at TRA

- The employee agrees to comply with all requirements as outlined in this health and safety plan

- The employee's training records have been verified as complete and current for the employee's assignment at the task site.

Employee's name (printed) and signature:

Print Signature Date

Company of employment:

Field team leader's name (printed) and signature:

Print

Signature

Date 